\title{
DIAGNOSIS OF PROTEUS SPP. IN WILD BIRDS RAISED UNDER CAPTIVITY IN RIO GRANDE DO NORTE, BRAZIL
}

\section{R.G. Olinda, M.C.A. Souza, J.N. Figueiredo, J.M.C. Silva, N.D. Alves, F.S.B. Bezerra, F.M.C. Feijó}

Universidade Federal Rural doSemiárido, Departamento de Ciências Animais, Laboratório de Microbiologia Veterinária, CP 137, CEP 59625-900, Mossoró, RN, Brasil. E-mail: rgumes@hotmail.com

\begin{abstract}
The aim of this work was to relate the occurrence of bacterial illnesses in two wild birds raised under captive conditions in Rio Grande do Norte State, Brazil, focusing on their clinical and microbiological findings. Clinical exams were performed in both birds in order to collect data and to determine the clinical and pathological outcome. In bird [A1] was diagnosed an infection in the respiratory system, and in bird [A2] the diagnosis was pododermatitis. Samples of shedding were collected using a sterile swab to perform a bacterial culture in blood agar and McConkey agar. An antibiogram was performed as well. The bacterial culture revealed the growing of Proteus sp. and Proteus vulgares, respectively. The antibiogram performed with the samples of bird [A1] showed the resistance to the follow antibiotics: ampicillin, amoxicillin/clavulanic acid, aztreonam, cefepime, ceftazidime, ciprofloxacin, tetracycline, sulfamethoxazole/trimethoprim and gentamicin. In bird [A2], strain was resistant to ampicillin, amoxicillin/clavulanic acid, aztreonam, cefotoxin, chloramphenicol, tetraciclin, sulfamethoxazole/trimethoprim and gentamicina. Proteus spp. appears to be a potencial multiresistant pathogen and causes severe lesions and diseases for wild birds in captivity.
\end{abstract}

KEY WORDS: Bacterial diseases, wild birds, antibiogram.

\section{RESUMO}

DIAGNÓSTICO DE PROTEUS SPP. EM AVES EXÓTICAS CRIADAS EM CATIVEIRO NO RIO GRANDE DO NORTE. O objetivo deste trabalho é relatar a ocorrência de enfermidades bacterianas em duas aves exóticas criadas em cativeiro no Rio Grande do Norte, com enfoque nos achados clínicos e microbiológicos. Realizou-se o exame clínico nas aves para a coleta de dados e caracterização do quadro clínico-patológico, sendo diagnosticada na ave [A1] infecção no trato respiratório superior, e na ave [A2] pododermatite profunda. O material biológico das secreções foi colhido com o auxílio de swabs estéreis para a determinação do agente etiológico através de cultura bacteriana em ágar sangue e ágar MacConkey. Realizou-se também o teste de susceptibilidade a antimicrobianos. A cultura bacteriológica das aves [A1] e [A2] resultou em crescimento de Proteus sp. e Proteus vulgares, respectivamente. O antibiograma da ave [A1] demonstrou resistência aos antibióticos: ampicilina, amoxicilina/ácido clavulâmico, aztreonam, cefepime, ceftazidima, ciprofloxacina, tetraciclina, sulfametoxazol/trimetroprim e gentamicina. Na ave [A2] a cepa isolada apresentou resistência a ampicilina, amoxicilina/ácido clavulâmico, aztreonam, cefoxitina, cloranfenicol, tetraciclina, sulfametoxazol/trimetroprim e gentamicina. Proteus spp. pode ser considerado um patógeno multirresistente, causador de lesões graves e doenças em aves selvagens criadas em cativeiro.

PALAVRAS-CHAVE: Enfermidades bacterianas, aves exóticas, antibiograma.

Wild animals, mainly birds, have become increasingly more popular and have been raised as pets for many people because of their colors, beauty and sounds (Gondim et al., 2006). Therefore, wild animal medical clinics have been growing because of the concerning with sanity of that kind of animals, as well as for the zoonotic potential of many birds diseases.

Gram-negative bacteria are related as the most frequent etiology in birds infections (FowLER; CuBAs, 2001). The knowledge about the bacterial characteristics could help us to understand how these microorganisms can cause diseases since they are part of the natural intestinal microbiota, being frequently reported as opportunistic microorganisms (Koneman et al., 2008).

Bacteria from Proteus sp. genus belong to Enterobacteriaceae family. They are bacilli Gramnegatives potentially pathogenic for birds, pointed as cause of foot lesions, and respiratory diseases such as air sacculitis and caseous pneumonia, when the animal has imunessupression (Godor; CuBAS, 2009). Therefore, the aim of this work was to relate the clinical and microbiological aspects of two wild birdsinfected with Proteus spp. and raised under captive conditions in Rio Grande do Norte, Brazilian northeast. 


\section{Case report}

The pieces of information described in this case report were obtained from two wild birds raised under captive conditions. The bird [A1] belonged to the Psittacidae family and Agapornis sp. genus. The bird [A2] belonged to the Spheniscidae family and Spheniscus magellanicus species. The birds, arisen from Mossoro and Natal city, respectively (both located in Brazilian Northeast), were sent to the Veterinary Microbiology laboratory, at Universidade Federal Rural do Semiárido (UFERSA).

During the anamnesis, the owner of the bird [A1] related a non-successful previous treatment using enrofloxacin and vitamin complex. The bird [A1] showed clinical signs suggestive of infection in the upper respiratory tract, like sinusitis, swollen head, depression, lacrimation and serupurulent nasal shedding. Clinical signs observed in bird [A1] are similar to those described by MARIETTOGonçalves et al. (2008), who studied diseases of the respiratory system in both domestic and wild birds.

The owner of the bird [A2] related various treatments using antibiotics prescribed by a veterinarian, but all without evidence of good response. The bird [A2] showed clinical signs suggestive of deep pododermatitis in the footpad region, evidenced by skin crusts with hyperemia and ulcer, lameness and chronic inflammation (Fig. 1). The bird [A2] showed lesions of grade 2 in the footpad, characterized by edema, erythema, ulcers, thickness of the skin (keratoderma), constrictions, exudation and proliferative lesions (RUPLEY, 1999).

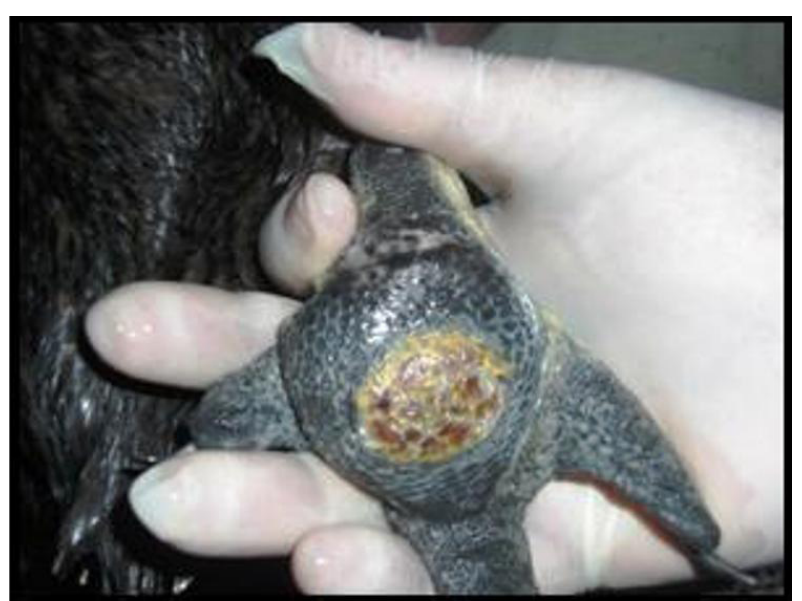

Fig. 1 - Macroscopic description of foot injury in the magellanic penguin (Spheniscus magellanicus).

From bird [A1], samples of the seropurulent nasal shedding were collected, while samples of the skin of footpad region were collected from bird [A2]. Samples were collected using sterile swabs, and then storage at $4^{\circ}$ to perform the microbiological exam. Samples were streaked on MacConkey and Blood agar and incubated under aerobic conditions for 48 hours at $37^{\circ} \mathrm{C}$. Developed bacterial colonies were transferred into a glass vial containing Brain and Heart Infusion Broth. Then, samples were identified based on macroscopic and morphotinctorial using Gram's method. Biochemical profile was defined as previously described by MACFADDIN (2000). Bacteriological results pointed Proteus sp. and Proteus vulgares for bird [A1] and [A2], respectively. The antimicrobial susceptibility test used was the diffusion method in agar (BARRY; THORNSBERRY, 1991), in which were tested the following antibiotics: aztreonam $(30 \mathrm{mg})$, cephalothin (30 mg), chloramphenicol (30 mg), gentamicin $(10 \mathrm{mg})$, tetracycline $(30 \mathrm{mg})$, ceftriaxone $(30 \mathrm{mg})$, amikacin (30 mg), cefepime (30 mg), ampicillin (10 mg), ciprofloxacin $(05 \mathrm{mg})$, sulfazatrim $(25 \mathrm{mg})$, amoxicillin/ clavulanic acid (30 mg), piperacillin / tazabactam (110 $\mathrm{mg}$ ), ceftadizina (30 mg) and cefoxitin (30 mg).

Many microorganisms known ordinarily as non-pathogenic can cause infection and disease, what has been directly related to changes in defense mechanisms of the host (Souza; Scarcelli, 2000). Thus, bacteria from Proteus sp. genus, found either in humans or in other animal species, are considered opportunistic microorganisms, causing diseases when the host is in an imunessupression condition, or when there are changes in their local microenvironment. In spite of Proteus sp. genus is often related to infections in the urinary tract, these bacteria can be isolated from many infected parts of the body (Brooks et al., 1998).

Bacteria are the most often etiology for respiratory tract diseases (RuPLey, 1999). Sometimes, these microorganisms are in development when there are bad environmental conditions or association with other infectious microorganisms. It is important to highlight that in the present case report sanitary and environmental manegement of the installations were not adequate. These factors are probably connected to the high level of stress and consequently to a decrease of the immune system, culminating with the bird disease.

Among infectious diseases of penguins raised under captive conditions, lesions on the feet are one of the most important causes of diseases (Fowler; CubAs, 2001). Pododermatitis has been described in many bird species, being the most frequents Galliformes, Anseriformes, raptors, penguins, Psittaciformes and Passeriformes (COOPER; HARRISON, 1994). Possible predisposing factors are humidity, poor hygiene, trauma and inadequate housing conditions (COOPER; Harrison, 1994). In relation to the origin and the time of the footpad lesion, our results are in agreement to that found in the specific literature, where show a short time in duration. In addition, when one foot is affected, the other suffer with the overweight (COOPER, 2002), what can explain different degrees of the lesion, since the first affected foot has the most serious injury (Cubas; Godoy, 2004).

To our knowledge this is the first report of a pododermatitis in penguins caused by Proteus vulgaris. Other reports generally show Staphylococcus spp. as the main etiology cause of pododermatitis, being $S$. aureus the most prevalent species (RUPLEY, 1999; GUIMARÃES, 2006). In spite of been uncommonly reported, microorganisms 
of Proteus sp. genus can either cause occasionally pododermatitis in situations of immunesupression, frequently found under captive conditions.

The isolated microorganisms in this study presented resistance to the most antimicrobials tested. The antimicrobial susceptibility test revealed resistance in bird [A1] to ampicillin, amoxicillin/clavulanic acid, aztreonam, cefepime, ceftazidime, ciprofloxacin, tetracycline, sulfamethoxazole/trimethoprim and gentamicin. The sample from bird [A2] was resistant to ampicillin, amoxicillin/ clavulanic acid, aztreonam, cephalothin, chloramphenicol, tetracycline, trimethoprim/sulfamethoxazole and gentamicin. The microorganisms showed sensibility to the non-cited and tested antibiotics.

We truly believe that the probable cause of the multidrug resistance for antibiotics in the present study was indiscriminate and extended use of antibiotics, since these substances induce the selection of mutant and resistant pathogens (OliveIRA et al., 2005). This non-recommended practice is commonplace in the wild animals management, because the owners of this kind of animals raised in the Brazilian Semiarid region generally medicate their animals without consulting a veterinarian, or, the veterinarian is not familiar with the doses and protocols of the antibiotics for wild species. In spite of an adequate treatment and clinical accompaniment of the birds, Proteus spp. isolated in these two cases appears to be potencial pathogen a severe cause of lesions and diseases for those species being a resistant microorganism to many antimicrobials. Also, microbiologic exams are a good choice to establish the correct therapeutics protocol and avoid bacterial resistance.

\section{REFERENCES}

BARRY, A.L.; THORNSBERRY, C. Susceptibility tests: Diffusion Test Procedures. In: BALOWS, A.; HAUSER, W.J.; HERMANN, K.L.; ISENBERG HD, SHAMODY HJ. (E.d.). Manual of clinical microbiology. 5.ed. Washington, DC: American Society for Microbiology, 1991. p.1117-1125.

BROOKS, G.F.; BUTEL, J.S.; ORNSTON, L.N.; JAWETZ, E.; MELNICK, J.L.; ADELBERG, E.A. Microbiologia médica. 20.ed. Rio de Janeiro: Guanabara Koogan, 1998. 524p.

COOPER, J.E. Birds of prey: health and disease. Cowley: Blackwell, 2002. 345p.

COOPER, J.E.; HARRISON, G.J. Dermatology. In: RITCHIE, B. W.; HARRISON, G.J.; HARRISON, L.R. (Ed.). Avian medicine: principles and application. Flórida: Wingers Publishing, 1994. p.607-632.
CUBAS, Z.S.; GODOY, S.N. Algumas doenças de aves ornamentais, 2004. Disponível em: <http://canarilalmada.com/ download/download/Dossierdedoencas.pdf $>$. Acesso em: 2 de fev. 2011.

FOWLER, M.E.; CUBAS, Z.S. Biology, medicine and surgery of south american wild animals. Ames: Iowa State University Press, 2001. p.188-199.

GODOY, S.N.; CUBAS, Z.S. Principais doenças bacterianas e fúngicas em Psittaciformes - revisão. Clínica Veterinária, v.14, n.81, p.88-98, 2009.

GONDIM, L.S.Q.; GOMES, D.M.; MAIA, P.C.C. Casuística de aves selvagens atendidas de 2002 a 2004 na Escola de Medicina Veterinária da Universidade Federal da Bahia. In: CONGRESSO BRASILEIRO DE ZOOLOGIA, 26., 2006, Londrina. Resumos. Londrina, 2006. p.86-87.

GUIMARÃES, M.B. Passeriformes. In: CUBAS, Z.S.; SILVA, J.C.; CATÃO-DIAS, J.L. (Ed.). Tratado de animais selvagens. São Paulo: Roca, 2006. p.324-339.

KONEMAN, E.W.; ALLEN, S.D.; JANDA, W.M.; SCHRECKENBERGER, P.C.; WINN JUNIOR, W.C.W. Diagnóstico microbiológico. Rio de Janeiro: Guanabara Koogan, 2008.1608p.

MAcFADDIN J.F. Biochemical tests for identification of medical bacterial. 3.ed. Philadelphia: Lawrence McGrew, Lippincott Williams \& Wilkins, 2000. 901p.

MARIETTO-GONÇALVES, G.A.; LIMA, E.T.; ANDREATTI FILHO, R.L. Doenças respiratórias em aves atendidas no Laboratório de Ornitopatologia da FMVZ-UNESP/Botucatu-SP, Brasil, nos anos de 2005 a 2006. Archives of Veterinary Science, v.13, n.1, p.40-45, 2008.

OLIVEIRA, L.C.; MEDEIROS, C.M.O.; SILVA, I.N.G.; MONTEIRO, A.J.; LEITE, C.A.L.; CARVALHO, C.B.M. Susceptibilidade a antimicrobianos de bactérias isoladas de otite externa em cães. Arquivo Brasileiro de Medicina Veterinária e Zootecnia, v.57, n.3, p.405-408, 2005.

RUPLEY, A. E. Manual de clínica aviária. São Paulo: Roca, 1999.

SOUZA, C.A.I.; SCARCELLI, E. Agressão por microrganismos da microbiota endógena. Arquivos do Instituto Biológico, São Paulo, v.67, n.2, p.275-281, 2000.

Received on $12 / 3 / 11$

Accepted on $30 / 4 / 12$ 